\title{
Immunocytochemical Study of Rabbit-Polyclonal to Mycobacterium Tuberculosis, AB905: Improving Diagnostic of Tuberculous Lymphadenitis
}

Kajian Imunositokimia Rabbit-Polyclonal to Mycobacterium Tuberculosis, AB905: Meningkatkan Diagnostis Limfadenitis Tuberkulosis

\author{
Humairah Medina Liza Lubis ${ }^{1 *}$, Emni Purwoningsih², Ance Roslina ${ }^{3}$, Muhammad Al Anas ${ }^{4}$ \\ ${ }^{1}$ Department of Anatomical Pathology, Faculty of Medicine, Universitas Muhammadiyah Sumatera Utara \\ ${ }^{2}$ Department of Biochemistry, Faculty of Medicine, Universitas Muhammadiyah Sumatera Utara \\ ${ }^{3}$ Department of Microbiology, Faculty of Medicine, Universitas Muhammadiyah Sumatera Utara \\ ${ }^{4}$ Faculty of Medicine, Universitas Muhammadiyah Sumatera Utara
}

DATA OF ARTICLE:

Received: 22 Apr 2021

Reviewed: 29 June 2021

Revised: 01 July 2021

Accepted: 07 July 2021

*CORRESPONDENCE:

humairahmedina@umsu.ac.id

DOI:

10.18196/mmjkk.v21i2.11559

TYPE OF ARTICLE:

Research

\begin{abstract}
Tuberculous lymphadenitis (TBLN) is the most common form of extrapulmonary tuberculosis. However, the optimal diagnosis using Fine-Needle Aspiration Cytology (FNAC) or excisional biopsy is uncertain. This research aims to improve the diagnostic of TBLN with FNAC and immunocytochemistry (ICC) compared to the response to antituberculosis therapy. The cross-sectional study involved 43 patients with the criteria for TBLN diagnosis based on the appropriate clinical history of tuberculosis and indicative cytological results. Immunocytochemical examination employed rabbit-polyclonal to Mycobacterium tuberculosis (MTB) antibody (AB905). The MTB expression was found in 35 out of 43 cases $(81 \%)$ that appropriate cytological features of the tuberculosis process. Meanwhile, eight out of 43 cases (19\%) did not express MTB. Diagnostic tests for lesions with a positive cytologic appearance of TBLN and ICC were compared to the response to anti-tuberculosis therapy, revealing the sensitivity, specificity, positive predictive value, and negative predictive value of $95.2 \%, 75 \%, 95.2 \%$, and $17 \%$, respectively. Besides, Fisher's exact tests utilized to identify the relationship between two variables; $\mathrm{p}<0.05$ was considered significant. This research found immunocytochemical study was a sensitive and specific tool for improving the diagnostic of TBLN.
\end{abstract}

Keywords: cytology; fine-needle aspiration biopsy; immunocytochemistry; diagnostic; tuberculous lymphadenitis

\footnotetext{
Abstrak: Limfadenitis tuberkulosis (LNTB) merupakan bentuk tuberkulosis ekstrapulmonal yang paling umum. Diagnosis menggunakan sitologi aspirasi jarum halus (FNAC) atau biopsy eksisi. Penelitian ini bertujuan untuk membuktikan diagnosis LNTB berdasarkan pemeriksaan FNAC dan imunositokimia (ISK) dengan membandingkan respons terapi antituberkulosis. Metode cross sectional yaitu 43 pasien dengan kriteria diagnosis LNTB didasarkan pada riwayat klinis tuberkulosis dan hasil sitologi indikatif. Pemeriksaan ISK dilakukan dengan rabbit-polyclonal Mycobacterium tuberculosis (MTB) antibody (AB905). Ekspresi MTB terlihat pada 35 dari 43 kasus (81\%) menunjukkan gambaran sitologi dari proses tuberkulosis. Sedangkan 8 dari 43 kasus (19\%) tidak mengekspresikan MTB. Uji diagnostik lesi dengan gambaran sitologi LNTB dan ISK positif. Respons pengobatan anti tuberkulosis diperoleh sensitivitas, spesifisitas, nilai duga positif, dan negatif sebesar 95.2\%, 75\%, 95.2\%, dan 17\%. Tes Fisher menentukan hubungan antara dua variabel $p<0,05$. Penelitian menemukan imunositokimia adalah alat yang sensitif dan spesifik untuk diagnosis limfadenitis tuberculosis.
} 


\section{INTRODUCTION}

Tuberculous lymphadenitis (TBLN) is the most common form of extrapulmonary tuberculosis, with approximately one million cases worldwide each year. The disease is caused by Mycobacterium tuberculosis (MTB) and is often associated with the reactivation of latent infections. ${ }^{1,2,3}$

The diagnosis of tuberculous lymphadenitis is a challenge for pathologists because of various cytological features, such as cases of non-MTB infection, other systemic disease diagnoses, and neoplastic. Another difficulty is because MTB shows paucibacillary properties and an irregular distribution that tends to be clustered, resulting in very low sensitivity to Acid Fast Bacilli (AFB) smear and conventional culture. ${ }^{4}$

The diagnosis is usually confirmed by Fine Needle Aspiration, core biopsy, or open biopsy for microscopy, culture, cytology, or histology..$^{5}$ Fine Needle Aspiration is a simple examination technique. It is relatively painless, but the tissue obtained for examination is much less so that the diagnosis of lymphadenitis is sometimes difficult to establish. In contrast, core biopsy or open biopsy requires complex resources, such as operating rooms, surgical and anesthesia teams, and often leaves unpleasant scars on the patient despite being very informative about the histological structure. ${ }^{6}$ Hence, the optimal diagnostic approach is still unclear, and there is no diagnostic algorithm for testing tuberculous lymphadenitis, so the choice of examination rests with the clinician. In addition, not infrequently, patients with complaints of swollen lymph nodes with a clinical history showing the tuberculosis process are immediately given antituberculosis drug therapy and usually always respond well.

On the other hand, immunocytochemistry (ICC) is a sensitive and simple procedure. It is known that immunoreactive substances in the cytoplasm and cell wall of mycobacterium consist of proteins, lipids, and polysaccharides. Therefore, the present study aims to assess the presence of mycobacterial antigens by utilizing this examination. Recent studies have examined the performance of an immunocytochemical staining method (ICC) to detect MTB complex specific antigen using MPT64 in the extrapulmonary tuberculosis diagnostic. In that research, the UTI showed a sensitivity of $74.5 \%$ and specificity of $89.5 \%{ }^{7}$ Meanwhile, a study conducted by Prapanna and Srivastava detected MTB antigen using a polyclonal antibody to mycobacteria with a sensitivity and specificity of $96.92 \%$ and $95 \%{ }^{8}$

Thus, this research aimed to improve the diagnosis of tuberculous lymphadenitis with FNAC and immunocytochemistry compared to the response to antituberculosis therapy in patients who clinically show symptoms of extrapulmonary tuberculosis disease.

\section{MATERIALS AND METHOD}

\section{Study Design and Participants}

Between April 1, 2019, and December 31, 2020, a cross-sectional study was conducted by the Department of Anatomical Pathology, Universitas Muhammadiyah Sumatera Utara, Indonesia. Forty-three patients presented with lymphadenopathy of the neck and were clinically suspected to be of tubercular disease. All patients who had recently been diagnosed with tuberculosis and were on antitubercular treatment were withdrawn from the study. The participants were informed about the study procedure and the Health Research Ethical Committee of the Faculty of Medicine Universitas Sumatera Utara/H. Adam Malik General Hospital Medan granted ethics clearance.

\section{Fine-Needle Aspiration Cytology}

Under aseptic conditions, FNAC of the LN was performed under clinical guidelines with a needle of 23-gauge. 9,10 The aspirate was separated into three parts. For May-Grunwald Giemsa staining, one portion was smeared onto a slide and fixed immediately with $95 \%$ alcohol. For immunostaining of rabbit polyclonal to Mycobacterium tuberculosis antibody, two smeared slides were air-dried prepared.

\section{Cytological Evaluation}

An experienced pathologist examined a cytological analysis of lymph node aspirates by May Grunewald Giemsa stain. The appearance of dark specks (Group I) and darkened elliptical objects in lymph node aspirates was used to diagnose TBLN (Group II). ${ }^{11}$ 


\section{Immunocytochemistry Evaluation}

After removal, the slides were treated with phosphate-buffered saline (PBS) for a brief amount of time; they were incubated with hydrogen peroxide for half-hour to initiate the block of endogenous peroxidase activity. Once ingesting using the microwave antigen, the things were blocked with $5 \%$ normal serum horse (NHS) for fifteen minutes. Then, the primary antibody was applied (rabbit-polyclonal of MTB antibody, from Abcam, London, UK, diluted by 1/100) Liquid treatment) overnight and abruptly treated with Dako Real EnVision. The antigen was observed with diaminobenzidine (DAB), and hematoxylin was used for anti-staining.

\section{Immunostaining Evaluation}

Stained stuff was classified as positive and negative assessment. A positive assessment is if there is an expression appearance of brown color on the $M$. tuberculosis. Meanwhile, the assessment is negative if it fails to express a brown color, where at the same time, the positive control (from pleural fluids) displays a brown color.

\section{Antituberculous Drug Response}

Assessment of therapy response was based on neck lump reduction after administration of antituberculosis drugs for six months of use, and the patient did not complain of any abnormalities. Firstline antituberculous agents for the treatment of tuberculosis consisted of isoniazid, rifamycin (usually rifampin), ethambutol, and pyrazinamide.

\section{Statistical Analysis}

The results of cytological diagnosis and immunocytochemical staining were analyzed. For the antituberculosis drug response, the sensitivity, specificity, positive predictive value (PPV), negative predictive value (NPV), and the accuracy of cytology and immunocytochemistry were calculated. Fisher's exact test was used to statistically analyze the correlation between FNAC results, immunocytochemical staining, and antituberculosis drug response. If the $p$-value is $<0.05$, the difference is considered significant.

\section{RESULTS}

From April 2019 to December 2020, 43 lymph node aspirate samples were collected from patients who attended the anatomical pathology laboratory from April 2019 to December 2020. The age of the patients ranged from four to 70 years (median 28 years). In this study, females dominated, namely 27 females and 16 males (male to female ratio $=0.6$ ). Extrapulmonary sites involved were lymph nodes (32), supraclavicular (4), inguinal (2), breast (1), submandibular (1), malleolus (1), submental (1), and wrist joints (1).

All patients showed signs and symptoms based on the disease location. The main local symptoms were neck lumps, night sweats, loss of appetite, chest discomfort, and headaches.

The cytological findings of this study displayed the Dark Specks Features with Finely Granular Eosinophilic Amorphous Mass in the background and the darkened elliptical objects in the macrophage assembly. ${ }^{11}$ Table 1 summarizes the correlation between signs and symptoms and cytological findings.

Table 1. The Correlation between Signs, Symptoms, and Cytological Findings

\begin{tabular}{lcc}
\hline Signs and symptoms & Dark specks & Darkened elliptical objects \\
\hline Neck lumps & $21(49 \%)$ & $11(26 \%)$ \\
Night sweats & $2(5 \%)$ & $1(2 \%)$ \\
Loss of appetite & $3(7 \%)$ & $1(2 \%)$ \\
Chest discomfort & $1(2 \%)$ & $0(0 \%)$ \\
Headaches & $2(5 \%)$ & $1(2 \%)$ \\
\hline
\end{tabular}




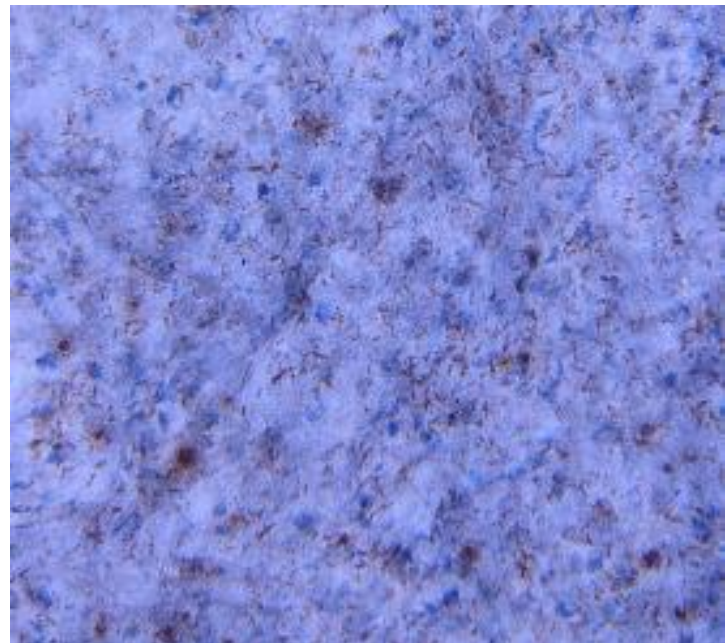

Figure 1. Positive Expression of Rabbit Polyclonal of Mycobacterium Tuberculosis Antibody in Dark Specks in the Entire Field of View (ICC, 400x)

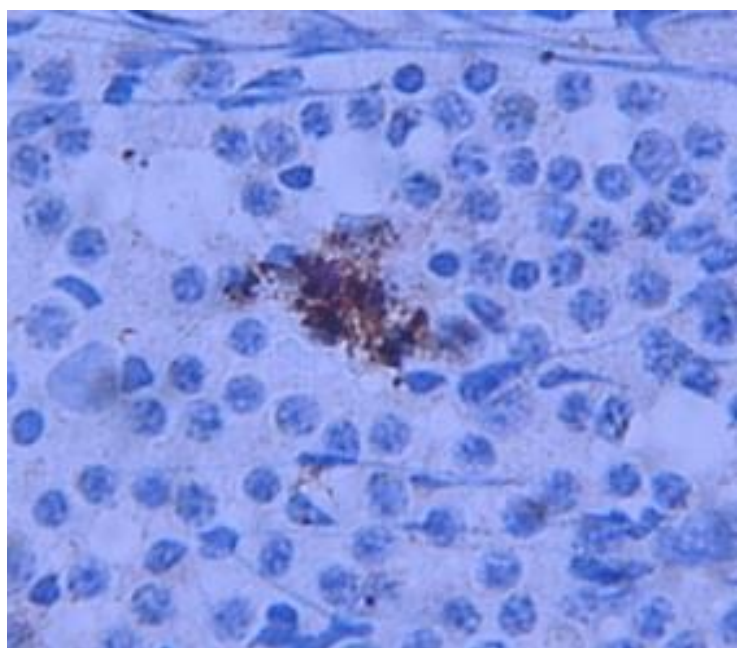

Figure 2. Positive Expression of Rabbit Polyclonal of Mycobacterium Tuberculosis Antibody in Darkened Elliptical Objects (ICC, 400x)

Table 2. The Correlation between Cytology Findings, Immunocytochemical Staining, and Antituberculous Drug Responses

\begin{tabular}{lccc}
\hline \multicolumn{1}{c}{ Category } & Cytology & $\begin{array}{c}\text { Immunocytochemical } \\
\text { positivity }\end{array}$ & $\begin{array}{c}\text { Antituberculous drug } \\
\text { responses positivity }\end{array}$ \\
\hline Dark specks & $25(58 \%)$ & $21(60 \%)$ & $20(62 \%)$ \\
Darkened elliptical objects & $18(42 \%)$ & $14(40 \%)$ & $12(38 \%)$ \\
\hline Total & 43 & 35 & 32 \\
\hline
\end{tabular}

Twenty-five of forty-three cases had dark specks features; twenty-one were immunocytochemically positive by rabbit-polyclonal to MTB antibody (AB905) (Figure 1); twenty were positive antituberculous drug responses. Eighteen of forty-three cases had dark oval body features; fourteen were immunocytochemically positive by rabbit-polyclonal to MTB antibody (AB905) (Fig. 2); twelve were positive antituberculous drug responses.

Therapeutic response was assessed from the same patient who was given antituberculosis drugs without any additional drugs for six months. The assessment was carried out by looking at the lump reduction every two weeks of re-control. From the results obtained, it was seen that 20 cases with dark specks cytology and 12 cases with cytological images of darkened elliptical objects showed a satisfactory therapeutic response. Overall displayed that the lump disappeared, and the patient did not complain of any abnormalities.

Table 2 presents the correlation between cytological findings, immunocytochemical staining, and antituberculous drug response.

Table 3. Immunocytochemical Staining with Dark Specks Features, Taking Antituberculous Drug Response as the Gold Standard

\begin{tabular}{ccccc}
\hline & & \multicolumn{2}{c}{ Antituberculous drug response } & \multirow{2}{*}{ Total } \\
\hline $\begin{array}{c}\text { Immunocytochemical staining } \\
\text { ab905 }\end{array}$ & Positive & Negative & $1 \mathrm{FP}$ & 21 \\
& Negative & $20 \mathrm{TP}$ & $3 \mathrm{TN}$ & 4 \\
\hline & & $1 \mathrm{FN}$ & 4 & 25 \\
\hline
\end{tabular}

TP, true-positive; FP, false-positive; FN, false-negative; TN, true-negative

Table 4. Immunocytochemical Staining with Darkened Elliptical Objects Features, Taking Antituberculous Drug Response as the Gold Standard

\begin{tabular}{cccc}
\hline & \multicolumn{2}{c}{ Antituberculous drug response } & \multirow{2}{*}{ Total } \\
\cline { 2 - 4 } & Positive & Negative & 14 \\
\hline Immunocytochemical staining & $12 \mathrm{TP}$ & $2 \mathrm{FP}$ & 4 \\
\hline ab905 & $2 \mathrm{FN}$ & $2 \mathrm{TN}$ & 18 \\
\hline
\end{tabular}

*TP, true-positive; FP, false-positive; FN, false-negative; TN, true-negative 
Compared to the antituberculous drug response, there were 20 cases of dark specks features (positive immunocytochemical staining and positive antituberculous drug response), one case (positive immunocytochemical staining and negative antituberculous drug response), one case (negative immunocytochemical staining and positive antituberculous drug response), and three cases (negative immunocytochemical staining and negative antituberculous drug response).

While in aspirates cytology of darkened elliptical objects features, there were 12 cases with positive immunocytochemical staining and positive antituberculous drug response, two cases (positive immunocytochemical staining and negative antituberculous drug response), two cases (negative immunocytochemical staining and positive antituberculous drug response), and two cases (negative immunocytochemical staining and negative antituberculous drug response) (Table 3,4).

The efficacy of FNAC of dark specks and immunocytochemical staining compared to antituberculous drug response as the gold standard was found to be good, with a sensitivity of $95.2 \%$, specificity of $75 \%$, PPV of $95.2 \%$, and NPV of $17 \%$.

On the other hand, the efficacy of FNAC of darkened elliptical objects and immunocytochemical staining compared to antituberculous drug response as the gold standard obtained a sensitivity of $85.7 \%$, a specificity of $50 \%$, a PPV of $85.7 \%$, and an NPV of $14.3 \%$. Fisher's exact tests were used to determine the relationship between two variables. $\mathrm{P}<0.05$ was considered significant.

\section{DISCUSSION}

Tuberculosis is the most common cause of adenopathy, aside from primary malignant tumors. Patients with TBLN are predominantly young and primarily present in cervical lymph nodes. Most participants are women, and it often highlights gender differences in the literature. ${ }^{12}$ The frequency of TBLN, which is more often found in women, cannot be explained until now.

Compared with the literature, most patients have unilateral cervical lymphadenopathy, especially on the left side; $75 \%$ complained of a mass in the neck, and none complained of cough. Recent studies have suggested that nearly $90 \%$ of TBLN cases appeared without TB symptoms elsewhere. ${ }^{13}$ In this study, it was only based on the data obtained on patient complaints without further examination of TB involvement elsewhere. As a result, the possibility of this infectious disease was more common than previously thought. Three-quarters of the cases in this study affected the cervical gland, which is similar to many other studies. ${ }^{14}$

TBLN is also the most common form of extrapulmonary tuberculosis. Behr and Waters proposed a theory that tuberculosis is regarded as a lymphatic disease with access to the lungs, explaining the specific involvement of the lymphatic system. This theory denies that TB is a primary lung disease. ${ }^{15}$ Unfortunately, this research does not prove this theory, and further research should be done.

On the other hand, Fine-Needle Aspiration Cytology (FNAC) is a simple, reliable, and inexpensive method to confirm the TBLN diagnosis. ${ }^{8,16,17}$ The superficial lymph nodes are easily collected by FNAC examination; the collected specimens can be used for cytology assessment, viewing ZN stained acid-fast bacilli, culture. Tuberculosis is diagnosed based on the presence or absence of necrotic granulomas and epithelioid cell granulomas, and dark specks and darkened elliptical objects are sometimes seen. ${ }^{11,18}$

Moreover, a definite diagnosis of TB is made based on the finding of MTB by an examination of ZN staining or culture. However, in patients with negative AFB, diagnosis is difficult. Prapanna and Srivastava's study used polyclonal antibodies to establish the tuberculosis diagnosis with negative ZN staining and culture to prove the existence of MTB in necrotic areas, the cytoplasm of macrophages, epithelioid cells, and giant cells. ${ }^{8}$ In this study, aspirate with dark specks image showed $60 \%$ of cases, and $40 \%$ of Darkened elliptical objects showed positive immunocytochemistry with rabbit-polyclonal to MTB antibody (AB905) stained in necrosis area and the distribution of macrophages. Previous studies have used more tissue material for immunohistochemical techniques because MTB antigen and tissue morphology can be appropriately evaluated. Unexpected background can be removed to give a specificity figure of $100 \% .{ }^{19}$ Nevertheless, this technique takes a long time compared to ICC that can be processed immediately after sampling.

In this study, the gold standard used was the response to anti-tuberculosis therapy based on an ex juvantibus diagnosis. We used this diagnosis based on several reasons. (1) Even though ZN staining is still considered the gold standard for tuberculosis, we did not use it. It is because none of the preliminary studies of the 20 cases reviewed with ZN were positive. This negative result is probably due to the length of time the aspirate preparation was fixed in alcohol. In the general procedure for ZN staining, it is best if the preparations are processed as soon as possible in a fresh smear condition because TB germs will die quickly or have difficulty growing at a temperature of $30^{\circ}-40^{\circ} \mathrm{C} .{ }^{20}$ Meanwhile, the aspirates we had collected so far were fixed with $96 \%$ alcohol and done a few months later, and it is likely that TB germs had died and could 
not be detected by ZN staining. (2) From the literature we obtained, ex juvantibus therapy can be given if several drugs that have been given do not show the results as expected. For example, in this study's case, we administered anti-tuberculosis drugs, and so far, all patients recovered (swelling disappeared) within sixnine months. This therapy is supported by the research by Lubis et al., which found the presence of TB bacilli in the two structures above. ${ }^{21}$

Further, our study verified the accuracy of immunocytochemical in the tuberculous lymphadenitis diagnosis. This study also found patients with positive cytological dark specks and immunocytochemical compared with therapeutic response, a sensitivity of $95.2 \%$, and a specificity of $75 \%$, respectively. Whereas with a cytological picture of darkened elliptical objects, a sensitivity of $85.7 \%$ and a specificity of $50 \%$ were obtained. Besides, Fisher's exact tests were used to determine the relationship between two variables; $p$ $<0.05$ was considered significant. In the literature, the FNAC sensitivity and specificity in the tuberculous lymphadenitis diagnosis vary greatly, ranging from 43 to $100 \% .22,23$ This difference can be seen in the cytological diagnosis of tuberculosis lymphadenitis. Based on experience, we can confirm that FNAC is a reliable, fast, and accurate method for diagnosing tuberculous lymphadenitis and can replace invasive biopsy.

\section{CONCLUSION}

In cases of lymphadenitis tuberculosis, FNAC and immunocytochemical may help to improve diagnostic accuracy.

\section{ACKNOWLEDGEMENT}

We thank all study participants for their cooperation, and this research was funded by Universitas Muhammadiyah Sumatera Utara.

\section{CONFLICT OF INTEREST}

There is no conclict of interest of this publication

\section{REFERENCES}

1. Wright CA, Path FRC, Burg M Van Der, Geiger D. Diagnosing Mycobacterial Lymphadenitis in Children Using Fine Needle Aspiration Biopsy: Cytomorphology, ZN Staining and Autofluorescence - Making More of Less. Diagn Cytopathol. 2008; 36 (4): 245-51. https://doi.org/10.1002/dc.20788

2. Moualed D, Robinson M, Qureishi A, Gurr P. Cervical Tuberculous Lymphadenitis: Diagnosis and Demographics, a Five-year Case Series in the UK. Ann R Coll Surg Engl. 2018; 100(5): 392-6. https://doi.org/10.1308/rcsann.2018.0021

3. Mathiasen VD, Andersen PH, Johansen IS, Lillebaek T, Wejse C. Clinical Features of Tuberculous Lymphadenitis in a Low-incidence Country. Int $J$ Infect Dis. 2020; 98: 366-71. https://doi.org/10.1016/j.ijid.2020.07.011

4. Handa U, Mundi I, Mohan S. Nodal Tuberculosis Revisited: A review. J Infect Dev Ctries. 2012; 6(1): 6-12. https://doi.org/10.3855/jidc.2090

5. Chakravorty S, Sen MK, Tyagi JS. Diagnosis of Extrapulmonary Tuberculosis by Smear, Culture, and PCR Using Universal Sample Processing Technology. J Clin Microbiol. 2005; 43 (9): 4357-62. https://doi.org/10.1128/JCM.43.9.4357-4362.2005

6. Knox J, Lane G, Wong JS, Trevan PG, Karunajeewa H. Diagnosis of Tuberculous Lymphadenitis Using Fine Needle Aspiration Biopsy. Intern Med J. 2012; 42(9): 1029-36. https://doi.org/10.1111/j.1445. 5994.2012.02748.x

7. Tadele A, Beyene D, Hussein J, Gemechu T, Birhanu A, Mustafa T, et al. Immunocytochemical Detection of Mycobacterium Tuberculosis Complex Specific Antigen, MPT64, Improves Diagnosis of Tuberculous Lymphadenitis and Tuberculous Pleuritis. BMC Infect Dis. 2014; 14 (1): 1-9. https://doi.org/10.1186/s12879. 014-0585-1

8. Prapanna P, Srivastava R, Arora, VK, Singh N, Bhatia A, and Kaur IR. Immunocytochemical Detection of Mycobacterial Antigen in Extrapulmonary Tuberculosis. Diagn Cytopathol. 2014; 42 (5): 391-5.

9. Aljafari AS, Khalil EAG, Elsiddig KE, El Hag IA, Ibrahim ME, Elsafi MEMO, et al. Diagnosis of Tuberculous Lymphadenitis by FNAC, Microbiological Methods and PCR: A Comparative Study. Cytopathology. 2004; 15 


\section{mutiara

(1): 44-8. https://doi.org/10.1111/j.1365-2303.2003.00119.x

10. Mittal P, Handa U, Mohan H and VG. Comparative Evaluation of Fine Needle Aspiration Cytology, Culture, and PCR in Diagnosis of Tuberculous Lymphadenitis. Diagn Cytopathol. 39 (11). https://doi.org/10.1002/dc.21472

11. Lubis, HML, Ganie, RA, Eyanoer, PC, Delyuzar D. Dark Specks and Dark Oval Bodies: Two Valuables Structures in Tuberculous Lymphadenopathy. In: 119th IASTEM International Conference. Kuala Lumpur: IRAJ; 2019. 1-4.

12. Fader T, Parks J, Khan NU, Manning R, Stokes S, Nasir NA. Extrapulmonary Tuberculosis in Kabul, Afghanistan: A Hospital-based Retrospective Review. Int J Infect Dis [Internet]. 2010; 14(2): e102-10. https://doi.org/10.1016/j.ijid.2009.03.023

13. Mathiasen VD, Hansen AK, Eiset AH, Lillebaek T, Wejse C. Delays in the Diagnosis and Treatment of Tuberculous Lymphadenitis in Low-Incidence Countries: A Systematic Review. Respiration. 2019; 97(6): 57684. https://doi.org/10.1159/000499052

14. Fontanilla JM, Barnes A, Von Reyn CF. Current Diagnosis and Management of Peripheral Tuberculous Lymphadenitis. Clin Infect Dis. 2011; 53(6): 555-62. https://doi.org/10.1093/cid/cir454

15. Behr MA, Waters WR. Is Tuberculosis a Lymphatic Disease with a Pulmonary Portal? Lancet Infect Dis [Internet]. 2014; 14(3): 250-5. https://doi.org/10.1016/S1473-3099(13)70253-6

16. Khillan R, Axiotis C, Sidhu G, Braverman AS. Fine Needle Aspiration (FNA) Cytology for Diagnosis of Cervical Lymphadenopathy. Int J Hematol. 2012; 95(3): 282-4. https://doi.org/10.1007/s12185-012-1024-y

17. Vimal S, Dharwadkar A, Chandanwale SS, Verma V, Khandelwal A. Fine Needle Aspiration cytology in the Diagnosis of Tuberculous lymphadenitis and Utility of Ziehl Neelsen Stain Benefits and Pitfalls. Int J Med Res Rev. 2016; 4 (8): 1466-75. https://doi.org/10.17511/ijmrr.2016.i08.30

18. Rammeh S, Romdhane E, Arfaoui Toumi A, Houcine Y, Lahiani R, Sassi A, et al. Efficacy of Fine-Needle Aspiration Cytology in the Diagnosis of Tuberculous Cervical Lymphadenitis. Acta Cytol. 2018; 62 (2): 99-103. https://doi.org/10.1159/000487503

19. Karimi S, Shamaei M, Pourabdollah M, Sadr M, Karbasi M, Kiani A, et al. Immunohistochemical Findings of the Granulomatous Reaction Associated with Tuberculosis. Int J Mycobacteriology. 2016; 5: S234-5. https://doi.org/10.1016/j.ijmyco.2016.11.001

20. McAdam AJ SA. Infectious Disease. In: Robbins and Cotran Pathologic Basis of Disease. Philadephia; 2005. 381-8.

21. Lubis HMND, Lubis HML, Lisdine HN. Dark Specks and Eosinophilic Granular Necrotic Material as Differentiating Factors between Tuberculous and Nontuberculous Abscesses. Maj Patol Indones. 2008; 17 (Mei): 49-52.

22. Abdissa K, Tadesse M, Bezabih M, Bekele A, Apers L, Rigouts L, et al. Bacteriological Methods as Add on Tests to Fine-needle Aspiration Cytology in Diagnosis of Tuberculous Lymphadenitis: Can They Reduce the Diagnostic Dilemma? BMC Infect Dis. 2014; 14 (1): 1-6. https://doi.org/10.1186/s12879-014-0720-z

23. Muyanja D, Kalyesubula R, Namukwaya E, Othieno E, Mayanja-Kizza H. Diagnostic Accuracy of Fine Needle Aspiration Cytology in Providing a Diagnosis of Cervical Lymphadenopathy among HIV-infected Patients. Afr Health Sci. 2015; 15 (1): 107-16. https://doi.org/10.4314/ahs.v15i1.15 